Article

\title{
Investigating Private Sectors' Behavioral Intention to Participate in PPP Projects: An Empirical Examination Based on the Theory of Planned Behavior
}

\author{
Yanchun Zhang ${ }^{1}$, Jianglin Gu ${ }^{1}$, Ming Shan ${ }^{1, *(1)}$, Yazhi Xiao ${ }^{1}$ and Amos Darko ${ }^{2}$ (D) \\ 1 School of Civil Engineering, Central South University, Changsha 410004, China; zyc_csu@126.com (Y.Z.); \\ petergu123@foxmail.com (J.G.); xyzxiaoyazhi@163.com (Y.X.) \\ 2 Department of Building and Real Estate, The Hong Kong Polytechnic University, 11 Yuk Choi Rd., Hung \\ Hom, Kowloon, Hong Kong, China; amos.darko@connect.polyu.hk \\ * Correspondence: ming.shan@csu.edu.cn
}

Received: 28 June 2018; Accepted: 28 July 2018; Published: 1 August 2018

\begin{abstract}
The active involvement of private sectors in Public-Private-Partnership (PPP) projects is critical for sustainable development of the PPP mode. While there have been many studies on PPP in the literature, limited research has been conducted to investigate the critical factors that affect the intention of the private sector to participate in PPP projects. To bridge the knowledge gap, this study proposed a theoretical model based upon the theory of planned behavior (TPB), and then tested it based upon empirical data collected from China. Partial least squares structural equation modeling (PLS-SEM) was employed in testing the model. Results indicated that "perceived behavioral control", "governmental influence", and "private sectors' attitude toward PPP" were the three most significant latent variables affecting the intention of private sectors to participate in PPP projects; and "financial capability", "full compliance with PPP contracts", and "profitability" were the three most significant observable variables affecting the intention of the private sector. The research findings contribute to the body of knowledge about private sector involvement in PPP projects in a Chinese context, and also provide solid support for the government to issue relevant polices or undertake reforms to attract more private sectors to participate in the PPP projects.
\end{abstract}

Keywords: public-private partnership; private sector participation; theory of planned behavior; structural equation modeling

\section{Introduction}

Public-Private Partnership (PPP) refers to a long-term contractual agreement between public and private sector partners, which allows private sectors to provide some or all financing, design, construction, operation, and maintenance of infrastructure assets and ancillary services [1,2]. PPP—originally known as Private Finance Initiative (PFI) — was first introduced by the UK government in 1992 [3]. Since then, it has become a major funding source for major capital projects [4,5]. The benefits of PPP have been widely recognized and well documented. For instance, it has been determined that PPP can: Help governments solve the problem of shortage of funds [6,7]; make use of the private sectors' technical skills and management expertise to achieve better risk sharing [4,8,9]; and help improve the efficiency and performance of public projects and services [6,10-13].

Private sector participation is an essential component of PPP [8]. According to Nisar [4] and Harris [14], the private sector is better at performing complex technical tasks, stimulating innovation, and adapting to rapid changes, compared to the public sector. These capabilities of the private sector would be highly helpful for making traditional public-sector procurement more successful 
and productive [1]. Likewise, the Asian Development Bank [1] believed that there are significant advantages associated with expanding the role of the private sector in financing and implementing infrastructure-related services because the participation of the private sector can help to overcome the "borrowing limit" challenge faced by the government; it can also help to implement the projects more cost-effectively and efficiently. In addition, Bohun [1] highlighted that active participation of the private sector in all phases of the project life cycle may help to secure better Value-For-Money in the project than the traditional "design-build" model, where the private sector's role is mainly limited to the project construction phase.

PPP has been widely adopted worldwide in the past decades [15-17]. However, in China, PPP did not experience rapid development until 2014, when the central government started promoting it actively across the country. The main aim of the government in taking such an action was to ease its financial burden by attracting investment from the private sector [18]. According to the statistics released by the China Public Private Partnerships Center, China has become one of the largest PPP markets in the world. From January 2014 to March 2018, 6955 PPP projects were contracted by the government of China, with a total investment of 10.02 trillion Chinese Yuan (approximately USD 1.60 trillion). However, most of the enterprises that won the PPP projects were state-owned (or public sector) enterprises. Clearly, this goes contrary to the intention of the Chinese government to reduce its financial burden by promoting the PPP concept. Moreover, although a variety of measures have been taken by the central government to encourage the private sector to participate in PPP projects in the past two years, the level of private sector involvement is still relatively low. Therefore, it is necessary and imperative to investigate the factors that affect private sector participation in PPP projects in China.

Although numerous PPP-related studies have been carried out in the past, most of the previous studies investigate risk management in PPP projects [19,20], pricing in PPP projects [21,22], and how the public sector should select private partners [23,24]. Little is known about the private sectors' intention to participate in PPP projects. The present study aims at contributing towards bridging the knowledge gap by exploring the critical factors that affect the private sectors' intention to participate in PPP projects. From the perspective of practice, which might be more important, the findings of this study could help government to formulate effective policies, or undertake institutional reforms, to foster the private sector involvement in PPP projects. The rest of this paper is organized as follows. Section 2 presents some background information and the research model and hypotheses, based on the theory of planned behavior (TPB) and the relevant literature. Section 3 describes the research methodology. Section 4 presents the data analysis and results. Section 5 discusses the key factors affecting the private sectors' intention of participating in PPP projects. Section 6 then concludes the study.

\section{Background, Research Model, and Hypotheses}

\subsection{Background}

Although it has been more than three decades since PPP was first introduced in China in the 1980s, PPP has only recently experienced widespread adoption in China. This could be ascribed to two reasons. First, as a transition economy that gradually changed from centrally planned economy to a market economy, China did not have a dynamic and vibrant private sector until the 2010s [25]. As a result, the private sector in China was not able to contribute towards the PPP projects implemented before the 2010s. Second, as a country that advocates socialism and communism, China is cautious and conservative about the role of the private sector within some economic fields, especially the infrastructure and public service fields [26]. Therefore, the government might have erected some barricades intentionally to prevent the private sector from engaging in these fields. However, in recent years, the Chinese government has aimed at promoting PPP in almost every field of the economy. Since 2013, the speed of China's economic growth has entered the descent phase, and the debt risks of governments at different levels have gradually become apparent. Consequently, the central 
government of China has decided to promote the application of PPP in the infrastructure and public services fields across the country. In this initiative, it is the aims of the government to attract massive social capital with a small amount of state-owned capital; make use of the private sectors' advanced technologies and skills; and hone the efficiency and performance of the projects in the fields of infrastructure and public services eventually.

Figures 1 and 2, which were created based upon the statistics released by the China Public Private Partnerships Center, present trends in the Chinese PPP projects from 2014 to 2017. As shown in Figure 1, there was a sharp increase in the number of PPP projects in China from 2014 to 2017. Nevertheless, it could be observed from Figure 2 that around $70-80 \%$ of the investment in these projects was made by state-owned enterprises, while only $20-30 \%$ was made by private investors. Such a strong contrast indicates that the public sector is still playing the leading role in the Chinese PPP projects, a situation that goes against the government's original intention of promoting PPP projects. So as to reverse this situation, since 2015, the State Council and National Development and Reform Commission of China have issued 13 documents that aim at encouraging and attracting private sector participation in PPP projects [27-39]. Nonetheless, active participation from the private sectors in PPP projects still remains a challenge, as the private sector in China still holds a "wait-and-see" attitude regarding PPP projects.

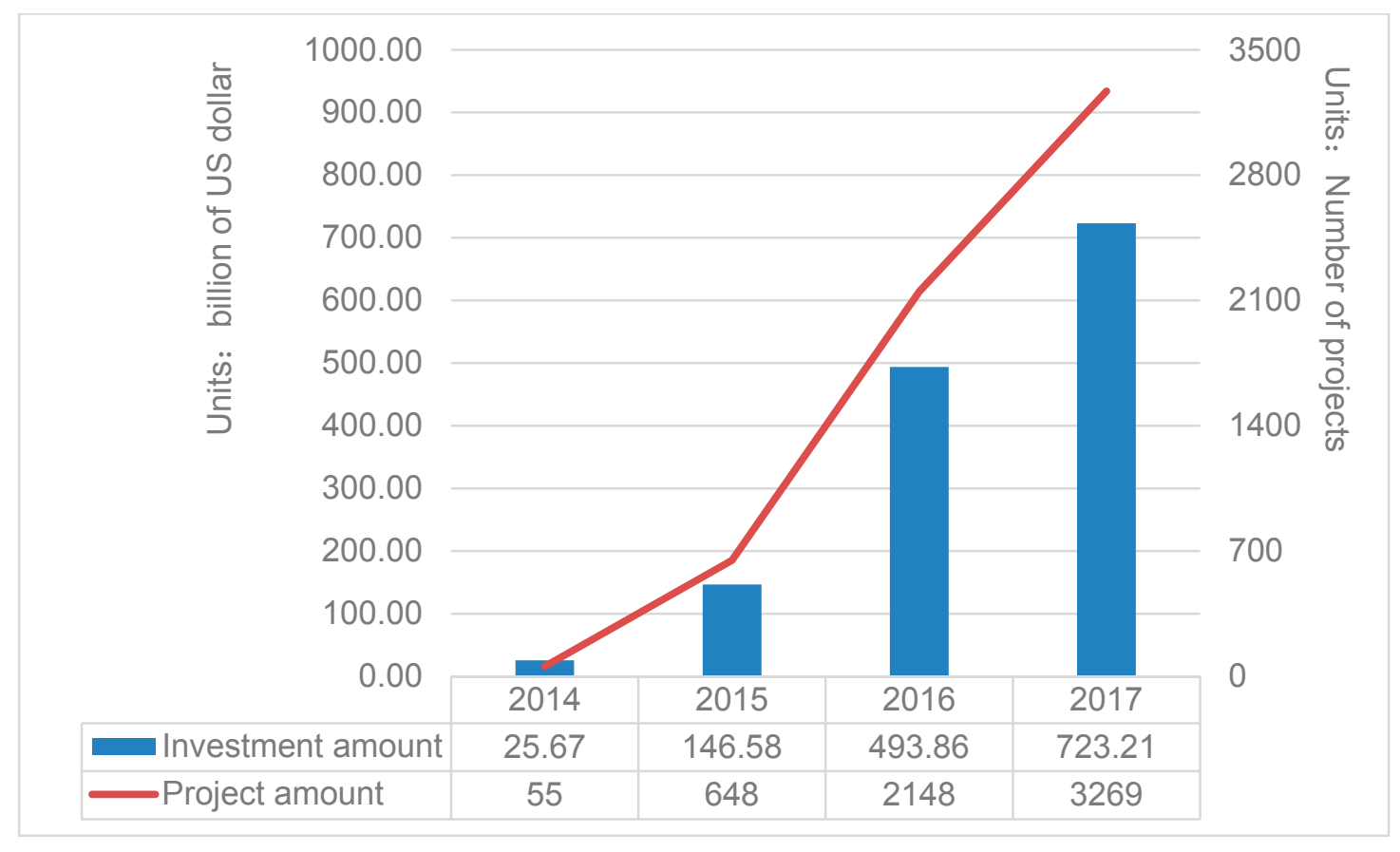

Figure 1. Trend in Contracted PPP Projects in China (2014 2017). 


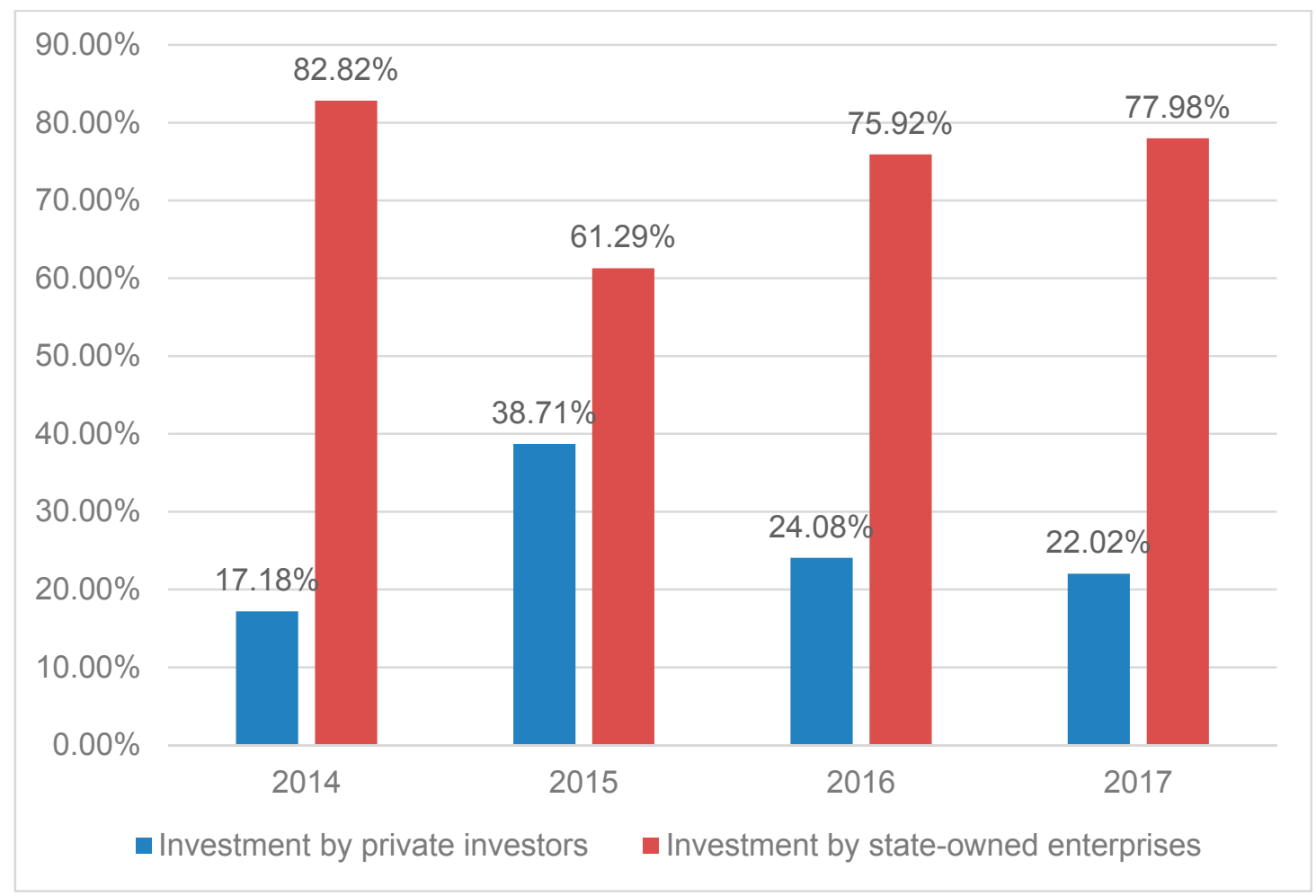

Figure 2. Details of the Contracted PPP Projects from Different Ownerships.

Therefore, it is urgent to examine the critical factors affecting private sector participation in PPP projects, and thereby understand how private sectors make their decisions on participating in PPP projects. The TPB, which originates from the theory of reasoned action (TRA), details the determinants of an individual's decision to perform a particular behavior [40]. According to the TPB, an individual's behavior is determined by his or her intentions to perform a particular behavior, and these intentions are affected by several latent variables, such as attitude toward behavior $(\mathrm{AB}$, i.e., the extent to which an individual believes that performing the behavior is favorable), subjective norm ( $\mathrm{SN}$, i.e., an individual's perception about the particular behavior, which is influenced by the judgments of "significant others", e.g., parents, spouse, and teachers), and perceived behavioral control (PBC, i.e., an individual's perceived ease or difficulty of performing the particular behavior) [40]. Although the TPB was originally developed for the study of individual behaviors, it has also been adopted by many studies to address different research problems at the organizational level. For instance, Koropp et al. [41] used the TPB to examine family firms' financial choices. Aibinu and Al-Lawati [42] developed a TPB-based theoretical structural model to identify the key factors determining the willingness of construction organizations to participate in e-bidding. Cheng [43] proposed a TPB framework to predict owners' intentions of adopting partnering contracts. Xian et al. [44] examined the formation of inter-organizational relational behaviors in megaprojects based on the TPB. Tang [45] also based upon the TPB to build a hypothetical model to examine contractors' bidding behavior within PPP projects. As the present research aims to investigate the critical factors affecting the intention of the private sector to participate in PPP projects, which falls inside the TPB's scope, it is appropriate to adopt the TPB to help address the research problem of this study.

\subsection{Research Model and Hypotheses}

Many studies have argued that the classical framework of TPB has a strong explanatory power [44,46]. Yet, several researchers made relevant modifications to the classical TPB model to suit their research studies. For instance, Karim et al. [47] introduced "situational factors" as a latent variable in the 
classical TPB model, together with attitude toward behavior (AB), subjective norm (SN), and perceived behavioral control (PBC), when investigating the intention of people to participate in food waste classification. Wu et al. [46] used the TPB in investigating contractors' behaviors in construction waste management. In their study, they modified the TPB model by including three additional latent variables, which were governmental supervision, economic viability, and project constraints. Song et al. [48] included demographic characteristics as a moderator variable between tourists' intentions and their behavior toward destination choice. As for Cheng [43], he analyzed stakeholders' intentions to initiate project partnering in Hong Kong, based upon the TPB. In his study, a new latent variable of perceived behavioral outcomes, which was included in the TPB model, was found to be significantly correlated to the stakeholders' attitude towards partnering.

In the present study, a novel latent variable—governmental influence (GI)—was proposed to be included in the classical TPB model. According to Wibowo, Alfen [49], Osei-Kyei and Chan [50], the government plays a key role in creating a favorable investment environment for private sectors, an environment that has a significant impact upon private sectors' participation in PPP projects. Furthermore, Wang et al. [51] indicated that the greatest risk in PPP projects in China is government policy risk. Additionally, Shan et al. [52-54] also highlighted the decisive role of the government in managing PPP projects within China. These previous studies suggest that the government has an important role in PPP projects. Given this important role, governmental influence was included in the TPB model developed for this study as one of the potential factors affecting the private sectors' intention of participating in PPP projects. Figure 3 shows the TPB model developed for this study. In this theoretical model, the private sectors' attitude toward PPP (PSAP), subjective norm of the private sector (SNPS) regarding PPP projects, perceived behavioral control (PBC) over participating in PPP projects, and governmental influence (GI) were hypothesized to be the four latent variables that could influence the behavioral intention of the private sector (BIPS) to participate in PPP projects.

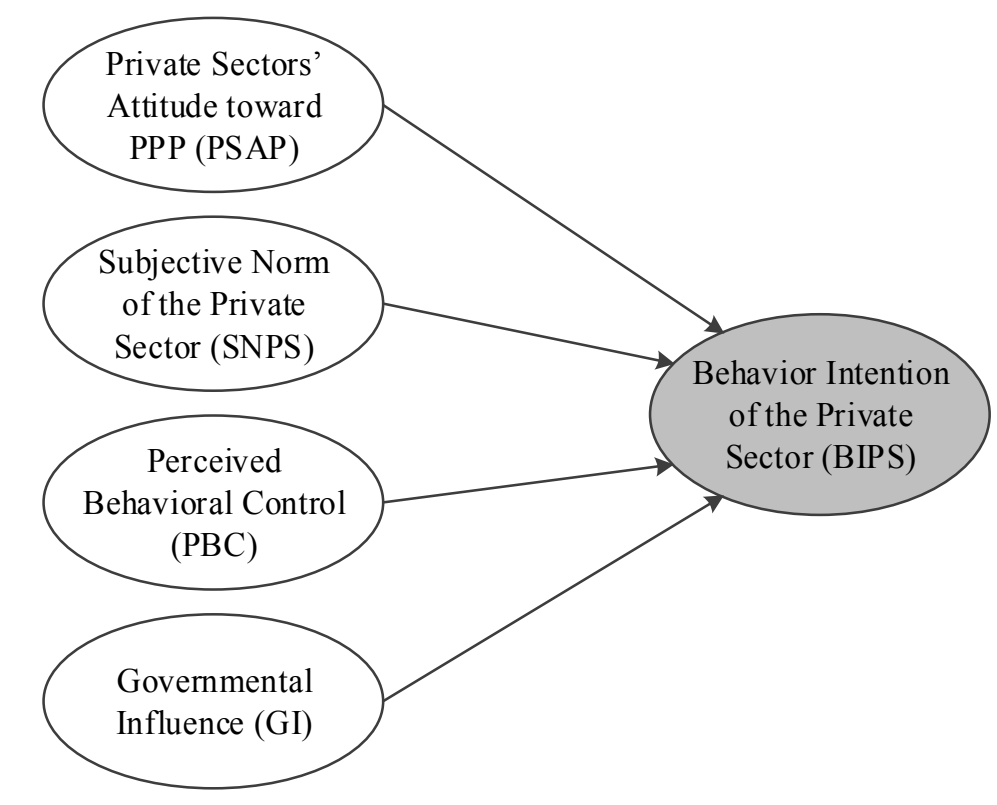

Figure 3. Hypothetical model of the factors influencing the private sectors' behavioral intention to participate in PPP projects.

The following hypotheses were proposed in the hypothetical model (Figure 3):

Hypothesis 1 (H1). The private sectors' attitude toward PPP projects has a direct and significant effect on the behavioral intention of the private sector to participate in PPP projects. 
Hypothesis 2 (H2). The subjective norm of the private sector regarding PPP projects has a direct and significant effect on the behavioral intention of the private sector to participate in PPP projects.

Hypothesis 3 (H3). The private sectors' perceived behavioral control over participating in PPP projects has a direct and significant effect on the behavioral intention of the private sector to participate in PPP projects.

Hypothesis 4 (H4). Governmental influence has a direct and significant effect on the behavioral intention of the private sector to participate in PPP projects.

These hypotheses are tested in this research, and the results are instructive in identifying the critical factors that affect the intention of the private sector to participate in PPP projects. Essentially, identifying and understanding such factors can assist the government in developing policies aimed at promoting the active participation of the private sector in PPP projects.

\subsection{Latent Variables and Observable Variables}

While observable variables can be considered as variables that can be directly measured, latent variables can be considered as variables that cannot be directly measured and can only be inferred from the observable variables [55]. Therefore, this study conducted a comprehensive literature review to identify observable variables that could be used to measure latent variables. During the literature review, the keywords of "Public-Private Partnership" and "PPP" were searched in Web of Science and China National Knowledge Infrastructure. Lastly, a total of 55 papers were identified $[3,4,7,16,49,50,56-104]$. These papers examine different PPP topics, such as private sectors' perception of PPP projects [56-59], driving forces for the private sector to participate in PPP projects [3,7,16,60-64], and critical success factors for the implementation of PPP projects [65-69]. All these topics are highly related to the research problem of this study. Thus, these papers are helpful and can be used to identify the observable variables that will be used to measure the latent variables of this study. The observable variables and the relevant latent variables are summarized in Table 1 and described below. 
Table 1. Latent variables and their corresponding observable variables.

\begin{tabular}{|c|c|c|c|}
\hline $\begin{array}{c}\text { Latent } \\
\text { Variables }\end{array}$ & Code & Observable Variables & Description \\
\hline \multirow{5}{*}{$\begin{array}{c}\text { Private sectors' } \\
\text { attitude } \\
\text { toward PPP } \\
\text { (PSAP) }\end{array}$} & PSAP1 & Profitability & Participation in PPP projects is profitable \\
\hline & PSAP2 & Gain access to the markets of infrastructure and public service & Participation in PPP projects contributes to access to the infrastructure and public service market \\
\hline & PSAP3 & Increase the market share & Participation in PPP projects contributes to increasing market share \\
\hline & PSAP4 & Benefit enterprise strategic development & Participation in PPP projects can promote enterprise development and strategic transformation \\
\hline & PSAP5 & Establish reputation and social image & Participation in PPP projects can establish company's reputation and social image \\
\hline \multirow{5}{*}{$\begin{array}{l}\text { Subjective } \\
\text { norm of } \\
\text { private sector } \\
\text { (SNPS) }\end{array}$} & SNPS1 & Competitors' attitudes toward PPP & Most of the competitors participate in PPP projects actively \\
\hline & SNPS2 & Encouragement from government & The government encourages private sectors to participate in PPP projects \\
\hline & SNPS3 & Attitude of industry associations toward PPP & Industry associations support my company to participate in PPP projects \\
\hline & SNPS4 & Financial sectors' attitude toward PPP & Cooperative financial institutions support my company to participate in PPP projects \\
\hline & SNPS5 & Attitudes of experienced private sectors & Private sectors with PPP experiences have a positive attitude towards PPP \\
\hline \multirow{6}{*}{$\begin{array}{c}\text { Perceived } \\
\text { behavioral } \\
\text { control (PBC) }\end{array}$} & PBC1 & Financial capability & My company has adequate funds to participate in PPP projects \\
\hline & PBC2 & Technical strength & My company has the technical strength to participate in PPP projects \\
\hline & РBC3 & Past experiences & My company has adequate PPP projects experiences \\
\hline & PBC4 & Borrowing capacity & My company can successfully obtain funds from financial institutions when participating in PPP projects \\
\hline & PBC5 & Good relationship with government & My company has good cooperative relationship with the government-the initiator of PPP projects \\
\hline & PBC6 & Information superiority & My company can easily acquire relevant information on the PPP projects to be initiated \\
\hline \multirow{8}{*}{$\begin{array}{l}\text { Governmental } \\
\text { influence (GI) }\end{array}$} & GI1 & Help create a fair and competitive PPP market & The government can help create a fair and competitive market for PPP projects development \\
\hline & GI2 & Complete legislations and workable policies & There are proper legislations and polices for PPP projects development \\
\hline & GI3 & Full compliance with PPP contracts & The government, as a party of PPP contract, can carry out contracts with integrity \\
\hline & GI4 & Government financial assistance & The government provides financial assistances to private companies participating in PPP projects \\
\hline & GI5 & Active coordination between private companies and financial sectors & $\begin{array}{l}\text { The government coordinates private companies and financial sectors actively, helping the former to raise } \\
\text { more funds for PPP projects }\end{array}$ \\
\hline & GI6 & Appropriate allocation of risks between government and private sector & The risks of PPP projects can be allocated fairly between the government and private sector \\
\hline & GI7 & Tax incentives & The government provides relevant tax incentives for PPP projects \\
\hline & GI8 & Limited intervention in the implementation of PPP projects & The government will not unreasonably interfere with the implementation of the PPP projects \\
\hline \multirow{5}{*}{$\begin{array}{l}\text { Behavior } \\
\text { intention of } \\
\text { private sector } \\
\text { (BIPS) }\end{array}$} & BIPS1 & Have intention to participate in PPP projects & My company intends to carry out PPP business \\
\hline & BIPS2 & Be willing to increase the proportion of PPP in business portfolio & My company is willing to increase the proportion of PPP business \\
\hline & BIPS3 & Be ready to participate in PPP bidding & My company will participate in bidding for PPP projects with high probability \\
\hline & BIPS4 & Have more interest in PPP projects & Compared to traditional projects, my company is more willing to participate in PPP projects \\
\hline & BIPS5 & Be willing to recommend partner companies to participate in PPP projects & My company is willing to recommend partner companies to participate in PPP projects \\
\hline
\end{tabular}




\subsubsection{Private Sectors' Attitude toward PPP}

In the classical model of TPB, individual's attitude toward behavior is determined by his or her belief about the behavior, and according to Ajzen [40], the term "belief" can be defined as the subjective probability that the behavior will achieve a certain outcome. Thus, the latent variable "private sectors' attitude toward PPP (PSAP)" in the theoretical model of this study was mainly measured by the private sectors' perception of the benefits it could gain from participating in PPP projects. As previous studies highlighted, participating in PPP projects can offer the private sector many technical and economic benefits. For example, from the economic perspective, the private sector may reap higher profits $[50,62,69,70]$, gain access to some new markets like infrastructure and public service $[4,17,56,76,90]$, and increase its market share [69-72]. From the perspective of enterprise development, the participation in PPP projects may benefit not only from the strategic transformation and development of an enterprise $[67,73]$, but also from the reputation and social image of the enterprise [68]. As a result, the following four observable variables, "profitability" (PSAP1), "gain access to the markets of infrastructure and public service" (PSAP2), "increase the market share" (PSAP3), "benefit enterprise strategic development" (PSAP4), and "establish reputation and social image" (PSAP5), were identified to measure the latent variable "private sectors' attitude toward PPP (PSAP)" in this study.

\subsubsection{Subjective Norm of Private Sector}

Subjective norm is the perceived social pressure to engage or not to engage in a behavior, and the measurement of it is typically achieved by asking respondents to identify the extent to which the "significant others" would approve the behavior [40]. In this study, the "significant others" mainly refer to the private sectors' competitors, government, industry associations, financial sectors, as well as the private sectors that already have experiences in conducting PPP projects. As asserted by Porter [74], Smith et al. [75], and Mol and Birkinshaw [76], a company's behavior and decisions are directly affected by those of its competitors. Thus, a private company's attitude toward PPP is also affected by its competitor's attitude toward PPP. The government is another important "significant other" for the private sector, because normally the government is the party who initiates most of the PPP projects and then invites the private sectors to participate in the projects $[49,50,77-79]$. Therefore, the government's attitude toward PPP can significantly affect the private sectors' attitude toward PPP projects. Industry associations also play an important role in affecting the intention of the private sector to participate in PPP projects. This is because industry associations represent the party responsible for making codes and norms that regulate the conducts of the private sector in PPP contracts [50,77-81]. The intention of the private sector to participate in PPP projects can also be greatly influenced by financial sectors. This is because sometimes the private sectors may need financial assistance from the financial sectors (e.g., banks) to support them to engage in PPP projects [3]. Moreover, the other private companies that have previously engaged in PPP projects are also "significant others", as their past experiences could be of much reference value to the private companies that are considering participating in PPP projects [82]. Accordingly, five observable variables, "competitors' attitudes toward PPP (SNPS1)", "encouragement from government (SNPS2)", "attitude of industry association toward PPP (SNPS3)", "financial sectors' attitudes toward PPP (SNPS4)", and "attitude of experienced private sectors (SNPS5)", were proposed to measure the latent variable "subjective norm of private sector (SNPC)" in this study.

\subsubsection{Perceived Behavioral Control}

Perceived behavioral control (PBC) refers to people's perceptions of their ability to perform a given behavior. It indicates an individual's or organization's competence, which comprises elements such as knowledge, technical strength, financial capability, and resources to perform the behavior [40]. In China, most of the PPP projects are infrastructure projects in which several complicated construction methods are widely adopted $[7,70,82-85]$. Thus, having sufficient technical strength is critical for 
private companies that would participate in PPP projects. In addition to the technical strength, the private companies must also have a solid financial foundation and strong borrowing capacity since PPP projects typically require huge investments [16,58,63,65,69,77,78,86-91]. Additionally, having a good relationship with the government is also important for private companies that wish to participate in PPP projects, as it can bring them numerous benefits, such as supportive policy, financial incentives, and advance notice on future PPP projects $[58,64,70,88,92,93]$. Furthermore, private companies that have previously conducted PPP projects might enjoy the advantage of easily drawing on their past experiences when considering whether to participate in a new PPP project $[58,83,91,94]$. In the light of the above issues, six observable variables- "financial capability (PBC1)", "technical strength (PBC2)", "past experiences (PBC3)", "borrowing capacity (PBC4)", "good relationship with government (PBC5)", and "information superiority (PBC6)" - were proposed to measure the latent variable "perceived behavioral control (PBC)" in this study.

\subsubsection{Governmental Influence}

As argued earlier, the government plays a vital role in the PPP sector. Typically, the government is not only the initiator of the PPP projects but also the chief regulator of the PPP market. It could significantly influence the intention of the private sector to participate in PPP projects, through its activities and policies relating to PPP projects. First, as one of the major contracting parties in PPP projects, the government is obliged to strictly comply with the PPP contracts [13]. This is because private companies might be hesitant towards participating in PPP projects if the government usually does not comply with PPP contracts. Second, as the chief regulator of the PPP market, the government has huge responsibilities of helping to create a fair and competitive PPP market [7,58,59], enacting relevant legislation and policies [61,65,69,78,87,95-98], allocating risks appropriately between itself and private companies $[63,65,70,77,79,97,99-102]$, and providing financial assistance to private companies to help them become involved in PPP projects $[16,63,66,73,82,103]$. Thus, eight observable variables, "help create a fair and competitive PPP market (GI1)", "complete legislations and workable policies (GI2)", "full compliance with PPP contracts (GI3)", "government financial assistance (GI4)", "active coordination between private companies and financial sectors (GI5)", "appropriate allocation of risks between government and private sector (GI6)", "tax incentives (GI7)", and "limited intervention to the implementation of PPP projects (GI8)", were proposed to measure the latent variable of "governmental influence (GI)".

\subsubsection{Behavioral Intention of the Private Sector}

Behavioral intention is assumed to capture the motivational factors that influence an individual's or organization's behavior. It refers to how hard people are willing to try, and of how much of an effort they are planning to exert, in order to perform the behavior [40]. In the theoretical model for this study, five observable variables, "have intention to participate in PPP projects (BIPS1)", "be willing to increase the proportion of PPP in business portfolio (BIPS2)", and "be ready to participate in PPP bidding (BIPS3)", were proposed to measure the latent variable "behavioral intention of private sector (BIPS)" [45].

\section{Research Methodology}

To investigate the critical factors that influence the intention of the private sector to participate in PPP projects, a three-step research methodology was employed. First, a comprehensive literature review, based upon which a theoretical, TPB-based model was proposed for this study, was conducted. Second, a survey questionnaire was developed based on the theoretical model and distributed to target respondents for data collection. Lastly, partial least squares structural equation modeling (PLS-SEM) was used to analyze the data collected from the questionnaire survey, to empirically test the proposed theoretical research model. Qualitative and quantitative methods were sequentially adopted in this study. It was expected that results obtained from different methods could triangulate and complement 
each other and yield stronger and more reliable findings eventually [97,104-106]. The conceptual map of the proposed methodology is shown in Figure 4.

Step 1: Propose a TPB-based theoretical model by comprehensive literature review.

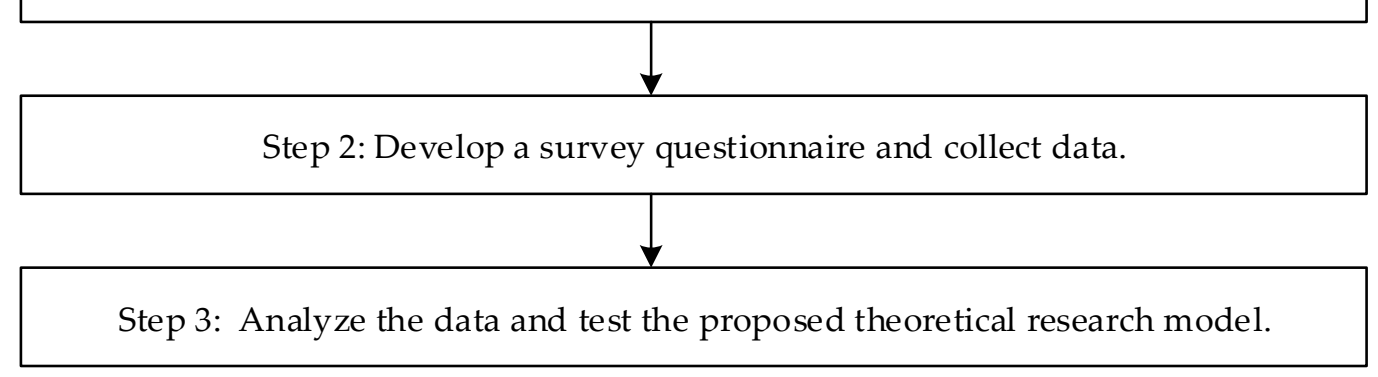

Figure 4. Conceptual map of the research methodology.

\subsection{Questionnaire Design and Data Collection}

In order to test the theoretical model and research hypotheses, a questionnaire survey was conducted to gather professionals' perceptions of private sectors' intention of participation in PPP projects. The survey questionnaire's development involved two steps. First, an initial version of the questionnaire was formed based on the observable variables identified from the literature review. Second, this initial questionnaire was validated with a focus group consisting of ten professors to ensure the accuracy and completeness of the questions. Based upon the feedback received, two new observable variables- "have more interest in PPP projects" and "be willing to recommend partner companies to participate in PPP projects" - were added to the survey (see Table 1). In essence, these two variables were used to improve the explanatory power of behavior intention of private sector (BIPS). The finalized questionnaire consisted of two sections. The first section was designed to collect the respondents' and their companies' background information, and the second section asked the respondents to rate the survey items using a five-point rating scale (from $1=$ strongly disagree to 5 $=$ strongly agree). The-five point rating scale has been more highly utilized than other scales such as the seven-point scale, nine-point scale, etc. The five-point rating scale is readily comprehensible to respondents and can produce evaluation results with higher reliability [107-109]. The target respondents for the questionnaire survey were employers and employees from the private sector in China. In order to reach these target respondents, the research team attended four promotion seminars and three training sessions for PPP projects held between March 2017 and March 2018. At each promotion seminar and training session, 50 hard copies of the questionnaire were randomly distributed among the attendees from the private sector. Additionally, the research team identified 38 private enterprises that had participated or had the intention to participate in PPP projects. A visit was paid to each of these private enterprises, and during each visit, in order to collect more opinions from more private sectors, at most five staff from each enterprise were requested to fill out the questionnaire. To ensure that their opinions can greatly reflect the company's attitude towards participation in PPP projects, most of the staffs invited to participate in this research were from the top and middle level management. A total of 500 questionnaires were distributed (including those distributed at the promotion seminars and training sessions, and those distributed during the visits to the private enterprises), and 332 valid replies were eventually received, yielding a satisfactory response rate of $66.4 \%$. It is noteworthy that the sample size and response rate were sufficient for conducting statistical analyses $[70,110,111]$. The background information of the respondents is shown in Table 2 . It could be observed that most of the respondents were top or middle level managers; most of them have PPP project experience; most of the surveyed companies are large or medium sized companies from a wide range of industries. Thus, the collected data were representative and had the potential to generate meaningful and useful findings. 
Table 2. Background of the respondents.

\begin{tabular}{|c|c|c|c|}
\hline Attributes & Categories & $\mathbf{N}$ & $\%$ \\
\hline \multirow{4}{*}{$\begin{array}{l}\text { Years of working in } \\
\text { private company }\end{array}$} & $<1$ year & 65 & $19.58 \%$ \\
\hline & $1-3$ years & 173 & $52.11 \%$ \\
\hline & $>3$ years & 94 & $28.31 \%$ \\
\hline & None & 56 & $16.87 \%$ \\
\hline \multirow{4}{*}{$\begin{array}{l}\text { Years of involvement in } \\
\text { PPP projects }\end{array}$} & $<1$ year & 142 & $42.77 \%$ \\
\hline & $1-3$ years & 72 & $21.69 \%$ \\
\hline & $3-5$ years & 52 & $15.66 \%$ \\
\hline & $>5$ years & 10 & $3.01 \%$ \\
\hline \multirow{4}{*}{ Job position } & Top managerial level & 31 & $9.34 \%$ \\
\hline & Middle managerial level & 177 & $53.31 \%$ \\
\hline & Professional & 65 & $19.58 \%$ \\
\hline & Others & 59 & $17.77 \%$ \\
\hline \multirow{4}{*}{ Company size ${ }^{a}$} & Large & 149 & $44.88 \%$ \\
\hline & Medium & 118 & $35.54 \%$ \\
\hline & Small & 46 & $13.86 \%$ \\
\hline & Micro & 19 & $5.72 \%$ \\
\hline \multirow{8}{*}{ Company Category } & Construction contractors & 138 & $41.57 \%$ \\
\hline & Developers & 74 & $22.29 \%$ \\
\hline & Other types of investment institutions & 13 & $3.92 \%$ \\
\hline & Cultural, sports and travel operators & 6 & $1.81 \%$ \\
\hline & Other types of operators & 11 & $3.31 \%$ \\
\hline & Integrated environment service provider & 22 & $6.63 \%$ \\
\hline & Materials and equipment suppliers & 26 & $7.83 \%$ \\
\hline & Technical service provider & 42 & $12.65 \%$ \\
\hline
\end{tabular}

${ }^{a}$ The classifications were adopted from the national bureau of statistics of China (http:/ / www.stats.gov.cn/tjgz/ tzgb/201801/t20180103_1569254.html).

\subsection{Partial Least Squares Structural Equation Modeling}

Structural equation modeling (SEM), a multivariate statistical analysis technique that can simultaneously carry out confirmatory factor analysis and path analysis within a single structural equation model, was considered to be one of the most appropriate methods to analyze relationships between latent variables [112,113]. There are two types of SEM, PLS-SEM and covariance-based structural equation modeling (CB-SEM). PLS-SEM has several advantages over CB-SEM, of which one of the most talked about is that PLS-SEM can handle small sample sizes [114]. Also, compared to CB-SEM, PLS-SEM has greater explanatory power for endogenous variables. In addition, previous studies have shown that PLS-SEM performs better than CB-SEM when dealing with highly skewed data [115], justifying the robustness of PLS-SEM outcomes. Therefore, the PLS-SEM algorithm was adopted to test the theoretical model in this study.

The PLS-SEM comprised several measurement models and a structural model. The basic PLS-SEM algorithm was composed of two parts. One part dealt with estimating the latent constructs' scores, while the other part dealt with calculating the final estimates of path coefficients in the final structural model. Affected by the unique structure of PLS-SEM algorithm, the results were also divided into two parts. Reliability and validity of the measurement models needed to be tested first, followed by evaluating relationships based upon path coefficients of the structural model [116].

When testing the reliability and validity of the measurement models, four indicators, composite reliability, factor loadings of observable variables on each latent variable, Cronbach's alpha, and average variance extracted (AVE), were used to conduct four types of tests of the measurement models: indicator reliability, internal consistency reliability, convergent validity, and discriminant validity tests [117-119]. 
Regarding the evaluation of the structural model, the significance and $t$-values of path coefficients were adopted with the aid of bootstrapping [117-119]. The significance and $t$-values of path coefficients were used to prove or disprove the hypotheses proposed in this study [42]. Path coefficients were then calculated to assess the relationships between the different latent variables.

\section{Data Analysis and Results}

\subsection{Inter-Group Comparison}

Considering that the respondents are from different companies and have different experiences (as shown in Table 2), it is necessary to conduct inter-group comparison to check whether there are significant differences in the perceptions of respondents in terms of their experiences and companies. Kruskal-Wallis test was conducted to perform the inter-group comparison in this study. The test is a rank-based non-parametric statistical test that has been widely used to check the potential differences among three or more different groups [120,121].

According to the Kruskal-Wallis test results in Table 3, only GI2 (Complete legislations and workable policies) and GI3 (Full compliance with PPP contracts) were perceived statistically different by respondents in terms of company size and company category respectively, and other observable variables were not perceived statistically different by respondents. The test results imply that the assessments of the respondents are basically unanimous and can be treated as a whole for the subsequent analysis [122].

Table 3. Kruskal-Wallis test results.

\begin{tabular}{cccccc}
\hline \multirow{2}{*}{$\begin{array}{c}\text { Observable } \\
\text { Variables }\end{array}$} & $\begin{array}{c}\text { Years of Working in } \\
\text { Private Company }\end{array}$ & $\begin{array}{c}\text { Years of Involvement } \\
\text { in PPP Projects }\end{array}$ & $\begin{array}{c}\text { Job } \\
\text { Position }\end{array}$ & $\begin{array}{c}\text { Company } \\
\text { Size }\end{array}$ & $\begin{array}{c}\text { Company } \\
\text { Category }\end{array}$ \\
\cline { 2 - 6 } PSAP1 & 0.342 & 0.079 & 0.412 & 0.423 & 0.630 \\
PSAP2 & 0.140 & 0.374 & 0.741 & 0.598 & 0.980 \\
PSAP3 & 0.223 & 0.750 & 0.591 & 0.698 & 0.801 \\
PSAP4 & 0.571 & 0.936 & 0.513 & 0.188 & 0.200 \\
PSAP5 & 0.448 & 0.219 & 0.704 & 0.373 & 0.394 \\
\hline SNPS1 & 0.881 & 0.454 & 0.848 & 0.763 & 0.517 \\
SNPS2 & 0.340 & 0.552 & 0.217 & 0.232 & 0.242 \\
SNPS3 & 0.601 & 0.300 & 0.584 & 0.859 & 0.954 \\
SNPS4 & 0.948 & 0.863 & 0.336 & 0.637 & 0.161 \\
SNPS5 & 0.928 & 0.210 & 0.733 & 0.839 & 0.554 \\
\hline PBC1 & 0.802 & 0.864 & 0.094 & 0.392 & 0.141 \\
PBC2 & 0.843 & 0.989 & 0.200 & 0.957 & 0.819 \\
PBC3 & 0.276 & 0.689 & 0.604 & 0.143 & 0.980 \\
PBC4 & 0.506 & 0.364 & 0.669 & 0.735 & 0.851 \\
PBC5 & 0.716 & 0.371 & 0.843 & 0.213 & 0.318 \\
PBC6 & 0.755 & 0.087 & 0.817 & 0.221 & 0.872 \\
\hline GI1 & 0.420 & 0.960 & 0.378 & 0.523 & 0.859 \\
GI2 & 0.987 & 0.767 & 0.436 & $0.035^{\mathrm{a}}$ & 0.171 \\
GI3 & 0.766 & 0.732 & 0.569 & 0.096 & $0.020^{\mathrm{a}}$ \\
GI4 & 0.388 & 0.159 & 0.941 & 0.212 & 0.064 \\
GI5 & 0.484 & 0.665 & 0.181 & 0.545 & 0.312 \\
GI6 & 0.437 & 0.773 & 0.428 & 0.215 & 0.517 \\
GI7 & 0.990 & 0.638 & 0.170 & 0.502 \\
GI8 & 0.158 & 0.341 & 0.058 & 0.058 \\
\hline
\end{tabular}


Table 3. Cont.

\begin{tabular}{cccccc}
\hline \multirow{2}{*}{$\begin{array}{c}\text { Observable } \\
\text { Variables }\end{array}$} & $\begin{array}{c}\text { Years of Working in } \\
\text { Private Company }\end{array}$ & $\begin{array}{c}\text { Years of Involvement } \\
\text { in PPP Projects }\end{array}$ & $\begin{array}{c}\text { Job } \\
\text { Position }\end{array}$ & $\begin{array}{c}\text { Company } \\
\text { Size }\end{array}$ & $\begin{array}{c}\text { Company } \\
\text { Category }\end{array}$ \\
\cline { 2 - 6 } BIPS1 & 0.963 & 0.977 & 0.676 & 0.996 & 0.868 \\
BIPS2 & 0.915 & 0.353 & 0.809 & 0.749 & 0.502 \\
BIPS3 & 0.672 & 0.121 & 0.260 & 0.233 & 0.339 \\
BIPS4 & 0.081 & 0.354 & 0.431 & 0.300 & 0.429 \\
BIPS5 & 0.899 & 0.574 & 0.468 & 0.416 & 0.736 \\
\hline
\end{tabular}

Notes: ${ }^{a}$ The Kruskal-Wallist test was significant at the significance level of 0.05 , suggesting statistical difference among respondents from different institutions.

\subsection{Measurement Model Analysis}

The hypothetical model (Figure 3) was analyzed using the software of SmartPLS 3.2.6; the results are presented in the following sections. Indicator reliability was measured by the factor loadings of the observable variables on each latent variable. Numerous researchers have discussed the threshold values of the standardized factor loading below which the observable variables should be excluded from the final model. Ning and Ling [118] suggested a threshold of 0.4, while Hair et al. [123] suggested 0.5. According to Fornell and Larcker [124], Chin [116], and Doloi [125], the best cut-off threshold value should be 0.7 , as in this case more than $50 \%$ of the variance in an observable variable could be ascribed to its respective latent variable. Therefore, this study adopted 0.7 as the cut-off threshold value, and because of this, seven observable variables (i.e., SNPS1, factor loading $=0.466$; PBC5, factor loading $=0.651 ;$ PBC6, factor loading $=0.692 ;$ GI4, factor loading $=0.589 ;$ GI5, factor loading $=0.626 ;$ GI7, factor loading $=0.612$; and BIPS4, factor loading $=0.684$ ) were excluded from the final model, as presented in Table 4. Subsequently, the modified model was rerun using SmartPLS 3.2.6, and it was found that all the factor loadings of the observable variables on each latent variable were greater than 0.7 (Table 5), demonstrating a satisfactory level of indicator reliability in the final structural model.

Internal consistency reliability is usually assessed by composite reliability and Cronbach's alpha. According to Hair et al. [117], all composite reliability values should be greater than 0.6. For Cronbach's alpha, which is helpful in understanding how well a latent variable is represented and measured by its observable variables, Fornell and Larcker [124], Tonglet et al. [126], and Nunnally [127] suggested that all Cronbach's alpha values should be greater than 0.60 to ensure that the observable variables can represent and measure latent variables at an acceptable level. Table 5 shows that the composite reliability and Cronbach's alpha of each latent variable are greater than 0.7, which shows high interconnections between the observable variables within the domain of a latent variable.

Convergent validity of latent variables has been widely used to ensure the connections and associations among the observable variables measuring a latent variable. In PLS-SEM, the commonly adopted method to measure the convergent validity of a measurement model is AVE [124]. Fornell and Larcker [124] and Hair et al. [117] suggested that all AVEs must be equal to or greater than 0.5 to ensure an observable variable is highly correlated with other observable variables designed to measure the same latent variable. According to the results in Table 5, all AVEs were greater than the threshold of 0.5 , indicating a satisfactory level of convergent validity. 
Table 4. Loadings of observable variables of measurement models.

\begin{tabular}{|c|c|c|}
\hline Observable Variables & Factor Loadings & Mean of Evaluation \\
\hline PSAP1 & 0.802 & 3.620 \\
\hline PSAP2 & 0.742 & 3.699 \\
\hline PSAP3 & 0.711 & 3.693 \\
\hline PSAP4 & 0.712 & 3.681 \\
\hline PSAP5 & 0.717 & 3.611 \\
\hline SNPS1 & $0.466^{\mathrm{a}}$ & 3.575 \\
\hline SNPS2 & 0.784 & 3.861 \\
\hline SNPS3 & 0.718 & 3.720 \\
\hline SNPS4 & 0.723 & 3.666 \\
\hline SNPS5 & 0.700 & 3.633 \\
\hline PBC1 & 0.800 & 3.509 \\
\hline PBC2 & 0.751 & 3.816 \\
\hline PBC3 & 0.760 & 3.825 \\
\hline PBC4 & 0.821 & 3.741 \\
\hline PBC5 & $0.651^{\mathrm{a}}$ & 3.623 \\
\hline PBC6 & $0.692^{\mathrm{a}}$ & 3.789 \\
\hline GI1 & 0.732 & 3.401 \\
\hline GI2 & 0.711 & 3.286 \\
\hline GI3 & 0.756 & 3.410 \\
\hline GI4 & $0.589^{a}$ & 3.325 \\
\hline GI5 & $0.626^{\mathrm{a}}$ & 3.395 \\
\hline GI6 & 0.706 & 3.419 \\
\hline GI7 & $0.612^{\mathrm{a}}$ & 3.416 \\
\hline GI8 & 0.723 & 3.482 \\
\hline BIPS1 & 0.805 & 3.855 \\
\hline BIPS2 & 0.829 & 3.479 \\
\hline BIPS3 & 0.769 & 3.620 \\
\hline BIPS4 & $0.684^{\mathrm{a}}$ & 3.364 \\
\hline BIPS5 & 0.735 & 3.614 \\
\hline
\end{tabular}

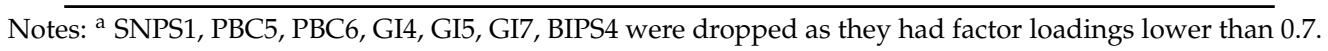

Campbell and Fiske [128] suggested that it is necessary to perform discriminant validity test to measure the extent to which a given observable variable is different from others. Cross-loadings analysis has been widely used to test the discriminant validity of measurement models; it was used in the present study as well. According to the results in Table 6, each of the observable variables had the highest loading on its respective latent variable, indicating an acceptable level of discriminant validity $[117,129,130]$. A further test for assessing discriminant validity of the measurement models requires comparing the correlations between the latent variables and square roots of AVEs. As suggested by Cenfetelli and Bassellier [131], the rule is that the square root of AVE of each latent variable should be larger than the correlation between two latent variables $[116,119,130]$. Table 7 compares the correlations between the latent variables and the corresponding square roots of AVE. The bolded diagonal numbers in the matrix are the square root of the AVE, which are greater than the off-diagonal elements in the corresponding rows and columns [132]. These results indicate that there are no correlations between two latent variables greater than the square roots of AVEs; thus, the discriminant validity of the measurement model is satisfactory. 
Table 5. Evaluation for revised model.

\begin{tabular}{|c|c|c|c|c|c|}
\hline Latent Variables & Observable Variables & Factor Loadings & Composite Reliability & Cornbach's $\alpha$ & AVE \\
\hline \multirow{5}{*}{ PSAP } & PSAP1 & 0.798 & 0.856 & 0.791 & 0.544 \\
\hline & PSAP2 & 0.744 & & & \\
\hline & PSAP3 & 0.713 & & & \\
\hline & PSAP4 & 0.710 & & & \\
\hline & PSAP5 & 0.719 & & & \\
\hline \multirow{4}{*}{ SNPS } & SNPS2 & 0.807 & 0.837 & 0.742 & 0.562 \\
\hline & SNPS3 & 0.724 & & & \\
\hline & SNPS4 & 0.750 & & & \\
\hline & SNPS5 & 0.715 & & & \\
\hline \multirow{4}{*}{ PBC } & PBC1 & 0.842 & 0.879 & 0.818 & 0.645 \\
\hline & PBC2 & 0.761 & & & \\
\hline & PBC3 & 0.778 & & & \\
\hline & PBC4 & 0.828 & & & \\
\hline \multirow{5}{*}{ GI } & GI1 & 0.741 & 0.859 & 0.796 & 0.550 \\
\hline & GI2 & 0.741 & & & \\
\hline & GI3 & 0.796 & & & \\
\hline & GI6 & 0.704 & & & \\
\hline & GI8 & 0.722 & & & \\
\hline \multirow{4}{*}{ BIPS } & BIPS1 & 0.846 & 0.877 & 0.812 & 0.640 \\
\hline & BIPS2 & 0.830 & & & \\
\hline & BIPS3 & 0.783 & & & \\
\hline & BIPS5 & 0.738 & & & \\
\hline
\end{tabular}

Table 6. Cross loadings of individual observable variables.

\begin{tabular}{cccccc}
\hline Observable Variables & PSAP & SNPS & PBC & GI & BIPS \\
\hline PSAP1 & $\mathbf{0 . 7 9 8}$ & 0.372 & 0.388 & 0.420 & 0.414 \\
PSAP2 & $\mathbf{0 . 7 4 4}$ & 0.261 & 0.376 & 0.332 & 0.388 \\
PSAP3 & $\mathbf{0 . 7 1 3}$ & 0.480 & 0.450 & 0.355 & 0.439 \\
PSAP4 & $\mathbf{0 . 7 1 0}$ & 0.363 & 0.427 & 0.410 & 0.315 \\
PSAP5 & $\mathbf{0 . 7 1 9}$ & 0.330 & 0.527 & 0.449 & 0.457 \\
\hline SNPS2 & 0.425 & $\mathbf{0 . 8 0 7}$ & 0.422 & 0.223 & 0.349 \\
SNPS3 & 0.340 & $\mathbf{0 . 7 2 4}$ & 0.387 & 0.247 & 0.234 \\
SNPS4 & 0.355 & $\mathbf{0 . 7 5 0}$ & 0.398 & 0.324 & 0.260 \\
SNPS5 & 0.347 & $\mathbf{0 . 7 1 5}$ & 0.403 & 0.322 & 0.290 \\
\hline PBC1 & 0.486 & 0.409 & $\mathbf{0 . 8 4 2}$ & 0.438 & 0.483 \\
PBC2 & 0.456 & 0.392 & $\mathbf{0 . 7 6 1}$ & 0.431 & 0.444 \\
PBC3 & 0.459 & 0.440 & $\mathbf{0 . 7 7 8}$ & 0.360 & 0.358 \\
PBC4 & 0.499 & 0.481 & $\mathbf{0 . 8 2 8}$ & 0.438 & 0.554 \\
\hline GI1 & 0.438 & 0.234 & 0.394 & $\mathbf{0 . 7 4 1}$ & 0.428 \\
GI2 & 0.418 & 0.326 & 0.407 & $\mathbf{0 . 7 4 1}$ & 0.412 \\
GI3 & 0.465 & 0.284 & 0.421 & $\mathbf{0 . 7 9 6}$ & 0.454 \\
GI6 & 0.290 & 0.245 & 0.289 & $\mathbf{0 . 7 0 4}$ & 0.308 \\
GI8 & 0.341 & 0.270 & 0.403 & $\mathbf{0 . 7 2 2}$ & 0.406 \\
\hline BIPS1 & 0.491 & 0.355 & 0.524 & 0.449 & $\mathbf{0 . 8 4 6}$ \\
BIPS2 & 0.493 & 0.374 & 0.520 & 0.467 & $\mathbf{0 . 8 3 0}$ \\
BIPS3 & 0.383 & 0.221 & 0.393 & 0.419 & $\mathbf{0 . 7 8 3}$ \\
BIPS5 & 0.392 & 0.259 & 0.415 & 0.418 & $\mathbf{0 . 7 3 8}$ \\
\hline
\end{tabular}


Table 7. Correlation matrix and square root of average variance extracted of constructs.

\begin{tabular}{ccccccc}
\hline Latent Variables & AVE & PSAP & SNPS & PBC & GI & BIPS \\
\hline PSAP & 0.544 & $\mathbf{0 . 7 3 7}$ & & & & \\
SNPS & 0.562 & 0.493 & $\mathbf{0 . 7 5 0}$ & & & \\
PBC & 0.645 & 0.593 & 0.537 & $\mathbf{0 . 8 0 3}$ & & $\mathbf{0 . 7 4 2}$ \\
GI & 0.550 & 0.534 & 0.367 & 0.522 & 0.548 & $\mathbf{0 . 8 0 0}$ \\
BIPS & 0.640 & 0.554 & 0.384 & 0.584 & & \\
\hline
\end{tabular}

In summary, indicator reliability analysis showed that all the observable variables adequately represent and measure their corresponding latent variables. Internal consistency reliability analysis showed that all the observable variables had good reliability. Convergent validity measures suggested that all the observable variables are related to the same latent variable they are measuring. Discriminant validity test of the measurement model indicated that only the observable variables in the same construct were related, the observable variables in different constructs were unrelated. The results of measurement model evaluation suggested that both the reliability and validity of the measurement model were adequate for the path analysis.

\subsection{Structural Model Analysis and Research Hypotheses Tests}

The paths between the different latent variables and thus the relevant research hypotheses were assessed using the bootstrapping technique. Table 8 shows the path coefficients and their corresponding $p$-values; it also shows the $t$-value associated with each structural path. According to Hair et al. [133], a $p$-value greater than 0.05 or a $t$-value smaller than 1.96 means that the hypothesis was disproved; a $p$-value lower than or equal to 0.05 while the $t$-value remains greater than or equal to 1.96 means that the hypothesis was proved at the significance level of 0.05 ; a $p$-value lower than or equal to 0.01 while the $t$-value is greater than or equal to 2.58 means that the hypothesis was proved at the significance level of 0.01 ; a $p$-value lower than or equal to 0.001 while the $t$-value is greater than or equal to 3.26 means that the hypothesis was proved at the significance level of 0.001 .

In conclusion, the PLS-SEM results suggested that:

(1) Hypothesis $1(\mathrm{H} 1)$, the private sectors' attitude toward PPP projects has a direct and significant effect on the behavior intention of the private sector to participate in PPP projects, was supported.

(2) Hypothesis $2(\mathrm{H} 2)$, the subjective norm of the private sector regarding PPP projects has a direct and significant effect on the behavior intention of the private sector to participate in PPP projects, was not supported.

(3) Hypothesis $3(\mathrm{H} 3)$, the private sectors' perceived behavioral control over participating in PPP projects has a direct and significant effect on the behavior intention of the private sector to participate in PPP projects, was supported.

(4) Hypothesis $4(\mathrm{H} 4)$, governmental influence has a direct and significant effect on the behavior intention of the private sector to participate in PPP projects, was supported.

Table 8. Path coefficient estimates and hypotheses testing.

\begin{tabular}{cccccc}
\hline Hypotheses & Path & $\begin{array}{c}\text { Standardized } \\
\text { Coefficient Estimate }\end{array}$ & $\boldsymbol{p}$-Value & $\boldsymbol{t}$-Value & Interpretation \\
\hline H1 & PSAP -> BIPS & 0.227 & 0.000 & 3.652 & $\begin{array}{c}\text { Supported } \\
\text { H2 }\end{array}$ \\
SNPS -> BIPS & 0.012 & 0.816 & 0.233 & Not Supported \\
H4 & PBC -> BIPS & 0.306 & 0.000 & 5.230 & Supported \\
\hline
\end{tabular}

The final PLS-SEM results supported three hypotheses- $-\mathrm{H} 1, \mathrm{H} 3$, and H4-each of which had an acceptable $p$-value below 0.001 (Table 8), indicating that these hypotheses were supported at the 0.001 
significance level. Only one hypothesis (H2) was not supported by the PLS-SEM results, as its $p$-value (0.816) was greater than 0.05 and its $t$-value $(0.233)$ was also less than 1.96 . Figure 5 presents the final structural equation model of factors influencing the intention of the private sector to participate in PPP projects.

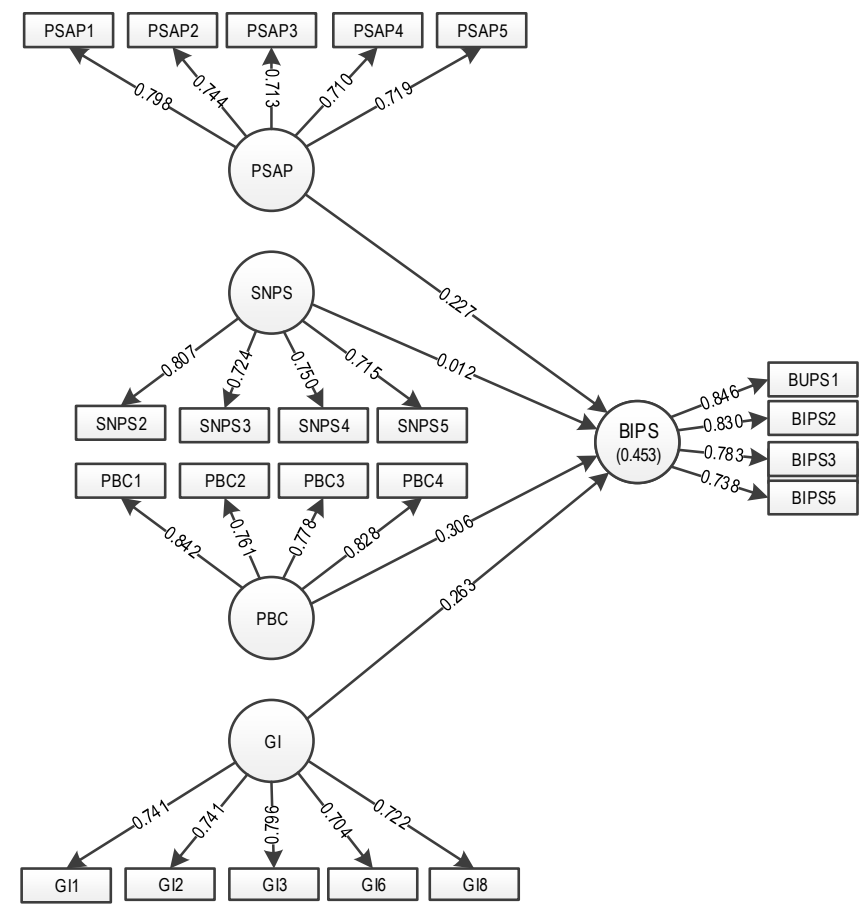

Figure 5. Final structural equation model of factors influencing the private sectors' intention to participate in PPP projects.

\section{Discussion}

It could be noted from Figure 5 that perceived behavioral control (PBC) is the most significant latent variable affecting the private sectors' intention of participating in PPP projects, because the link between PBC and BIPS had the highest path coefficient of 0.306. It could therefore be concluded that the private sectors' intention of participating in PPP projects is mainly affected by their own capabilities and resources. The more capabilities and resources the private sector has, the more willing it may be to participate in PPP projects. Among the observable variables under PBC, financial capability (PBC1) was found to be the most significant factor influencing the private sectors' intention to participate in PPP projects, because it received the highest factor loading of 0.842 . This finding might be attributed to the fact that most PPP projects are infrastructure projects that need a large amount of investment $[16,134]$, which requires the private sector to possess strong financial capabilities for participating in the PPP projects. The research findings implied that the private sector must ensure that it has a solid financial foundation before attempting to participate in PPP projects. Additionally, borrowing capacity (PBC4) was found to be another significant factor under PBC, as it received the second highest factor loading of 0.828 . This result indicates that borrowing capacity is also very critical to the private sectors' intention of participating in PPP projects, and is reasonable as borrowing capacity is highly associated with financial capability. To help the private sector's participation in PPP projects, the finding of this study could imply that the financial institutions should be willing, or the government should issue relevant polices to simulate them, to offer financial assistance to private companies that indicate their intention to participate in PPP projects. In fact, having strong borrowing capacity and financial capability can greatly help and increase the competence and capability of the private sector in performing PPP projects. 
The PLS-SEM results further showed that governmental influence (GI) was the second most significant latent variable affecting the private sectors' intention to participate in PPP projects, as the link between GI and BIPS received the second highest path coefficient of 0.263 . Among the observable variables under GI, full compliance with PPP contracts (GI3) was found to be the most influential factor (factor loading $=0.796$ ). The governments' full compliance with PPP contracts is fundamental for the success of PPP projects, and is also important for government credit [135]. This is consistent with Wang's [136] viewpoint that the greatest concern of 70\% of the private sectors participating in PPP projects has to do with the local government's credit risk. Many failed PPP projects have been due to unilateral defaults of governments, which have resulted in the loss of the private sectors. For example, in the Changchun Huijin Sewage Treatment PPP Project, because the government refused to pay sewerage treatment fees, a dispute arose and lasted for more than two years, which led to early termination of the cooperation contract and the government buying back the project [137].

Moreover, the results of this study indicated that the private sectors' attitude toward PPP (PSAP) was the third most significant latent variable affecting the intention of the private sector to participate in PPP projects, as the link between PSAP and BIPS had the third highest path coefficient which is 0.227. The willingness to perform a behavior represents, of course, a good starting point for individuals or organizations to perform the behavior. Holding positive attitudes about PPP, the private sector might not hesitate to participate in PPP projects. Among the five observable variables under PSAP, profitability (PSAP1) was found to be the most influential factor, as it had the highest factor loading of 0.798. This result shows that the biggest motivation for the private sector to participate in PPP projects is profitability, which is consistent with the capital nature of profit.

Ajzen [40] argued that attitude towards behavior and perceived behavioral control were internal factors relating to individuals or organizations themselves, while subjective norm is an external factor that relates more to the impacts exerted by "significant others" on them. In addition, he highlighted that internal factors are the main factors affecting the subject's behavior, which was also supported by the results of this research. As presented in Table 8, subjective norm of private sector did not significantly influence the intention of the private sector to participate in PPP projects (Path coefficient $=0.012$ ). This is in line with Tang's [45] finding that the Chinese private sectors' decision-making is usually less influenced by subjective norms. The correlation and regression analyses conducted by Cheng [43] also showed an insignificant relationship between subjective norms and construction organizations' intentions to form project partnering. The results of the present study suggest that external parties such as competitors, cooperative financial institutions, industry associations, and private enterprises having PPP experiences have little influence on the decision-making of the private sector in participating in PPP projects.

\section{Conclusions}

The private sectors' participation is core to forming a PPP. However, the private sectors' willingness to participate in PPP projects has been given very little attention. This study attempted to bridge the knowledge gap by investigating the critical factors that affect the private sectors' intention to participate in PPP projects. To this end, a theoretical model based on the TPB was proposed and then tested based on data collected from China through an empirical questionnaire survey with practitioners working in private companies. PLS-SEM was applied to analyze the data to test the proposed research model. The results indicated that "perceived behavioral control" was the most significant latent variable affecting the private sectors' intention to participate in PPP projects, followed by "governmental influence" and "private sectors' attitude toward PPP"; while "financial capability", "full compliance with PPP contracts", and "profitability" were the three most significant observable variables affecting the private sectors' intention. In contrast, the results showed that "subjective norm of private sector" had no significant effect on the private sectors' intention to participate in PPP projects, indicating that the private sector is not significantly affected by external parties like competitors, industry associations, and cooperative financial institutions when considering participating in PPP projects. 
This study is the first empirical investigation to examine the factors that affect the intention of the private sector to participate in PPP projects, making a significant contribution toward the PPP body of knowledge. In this study, hypothetical model was established based on the TPB, and according to the features of the subject investigated, governmental influence (GI) was introduced as the forth latent variable affecting private sectors' intention of participating in PPP projects, enabling the hypothetical model and observable variables more reasonable and systematic. Practically, this study concluded three most important observable variables affecting the private sectors' intention of participating in PPP projects, indicating that for private sectors, financial capability is the most important factor relating to their ability when considering participating in PPP projects, and for the governments, in order to attract private sectors' participation in PPP projects, they must improve the level of credit and provide reasonable rewards for the private sectors. The findings of this study are informative for policy makers to formulate effective strategies for encouraging the private sectors' participation in PPP projects.

Although the research objectives were achieved, there are limitations in this study. First, this research used opinion-based data and bias might be caused due to the different experiences, attitudes, and perceptions of the respondents. Second, the findings of this study were obtained in the context of China, and caution should be exercised when interpreting them in other countries. For future research, it would be very interesting to investigate the concerns of private sectors who do not wish to participate in PPP projects. It would also be imperative to develop a comprehensive set of strategies that can help in attracting the private sector to participate in PPP projects.

Author Contributions: Y.Z. provided good research advices and finished Sections 1 and 2, J.G. completed Sections 3 and 4. M.S. designed this study and revised the draft. Y.X. completed Sections 5 and 6. A.D. participated in proofreading the paper.

Funding: This research was funded by the Natural Science Foundation of Hunan Province of China (2018JJ2542).

Conflicts of Interest: The authors declare no conflict of interest.

\section{References}

1. Bohun, V. Developing Best Practices for Promoting Private Sector Investment in Infrastructure: Airports and Air Traffic Control; Asian Development Bank: Manila, Philippines, 2015.

2. Zhang, S.; Gao, Y.; Feng, Z.; Sun, W. PPP application in infrastructure development in China: Institutional analysis and implications. Int. J. Proj. Manag. 2015, 33, 497-509. [CrossRef]

3. Cheng, E.W.L.; Chiang, Y.H.; Tang, B.S. Alternative approach to credit scoring by DEA: Evaluating borrowers with respect to PFI projects. Build. Environ. 2007, 42, 1752-1760. [CrossRef]

4. Nisar, T.M. Implementation constraints in social enterprise and community public private partnerships. Int. J. Proj. Manag. 2013, 31, 638-651. [CrossRef]

5. Osei-Kyei, R.; Chan, A.P.C. Comparative analysis of the success criteria for public-private partnership projects in Ghana and Hong Kong. Proj. Manag. J. 2017, 48, 80-92. [CrossRef]

6. Cheng, Z.; Ke, Y.; Lin, J.; Yang, Z.; Cai, J. Spatio-temporal dynamics of public private partnership projects in China. Int. J. Proj. Manag. 2016, 34, 1242-1251. [CrossRef]

7. Effah, E.A.; Chan, A.P.C.; Owusu-Manu, D.G. Critical success factors for attracting private sector participation in water supply projects in developing countries. J. Facil. Manag. 2017, 15, 35-61.

8. Apurva Sanghi. Public Private Partnership Units: Lessons for Their Design and Use in Infrastructure; The World Bank: Washington, DC, USA, 2007.

9. Skietrys, E.; Raipa, A.; Bartkus, E.V. Dimensions of the efficiency of public-private partnership. Eng. Econ. 2015, 105, 45-50.

10. Erridge, A.; Greer, J. Partnerships and public procurement: Building social capital through supply relations. Public Adm. 2002, 80, 503-522. [CrossRef]

11. Shen, L.Y.; Platten, A.; Deng, X.P. Role of public private partnerships to manage risks in public sector projects in Hong Kong. Int. J. Proj. Manag. 2006, 24, 587-594. [CrossRef]

12. Yuan, J.; Wang, C.; Skibniewski, M.J.; Li, Q. Developing key performance indicators for public-private partnership projects: Questionnaire survey and analysis. J. Manag. Eng. 2011, 28, 252-264. [CrossRef] 
13. Zhang, S.; Chan, A.P.C.; Feng, Y.; Duan, H.; Ke, Y. Critical review on PPP research-A search from the Chinese and international journals. Int. J. Proj. Manag. 2016, 34, 597-612. [CrossRef]

14. Harris, F., Jr. How the Entrepreneurial Spirit Is Transforming the Public Sector. Foundation for Economic Education. 1993. Available online: https:/ / fee.org/articles/reinventing-government-how-theentrepreneurial-spirit-is-transforming-the-public-sector-from-schoolhouse-to-statehouse-city-hall-to-thepentagon-by-david-osborne-and-ted-gaebler (accessed on 1 June 2017).

15. Almarri, K.; Boussabaine, $\mathrm{H}$. The influence of critical success factors on value for money viability analysis in public-private partnership projects. Proj. Manag. J. 2017, 48, 93-106. [CrossRef]

16. Chan, A.P.C.; Yeung, J.F.Y.; Yu, C.C.P.; Wang, S.Q.; Ke, Y. Empirical study of risk assessment and allocation of public-private partnership projects in China. J. Manag. Eng. 2010, 27, 136-148. [CrossRef]

17. Geddes, R.R.; Reeves, E. The favourability of US PPP enabling legislation and private investment in transportation infrastructure. Util. Policy 2017, 48, 157-165. [CrossRef]

18. Wildau, G. China Admits to Disguised Fiscal Borrowing Risk. Financial Times, 3 August 2017. Available online: / /www.ft.com/content/5fe8b3c2-7754-11e7-90c0-90a9d1bc9691(accessed on 12 June 2018).

19. Chan, A.P.C.; Osei-Kyei, R.; Yi, H.U.; Yun, L.E. A fuzzy model for assessing the risk exposure of procuring infrastructure mega-projects through public-private partnership: The case of Hong Kong-Zhuhai-Macao bridge. Front. Eng. Manag. 2018, 5, 64-77. [CrossRef]

20. Yuan, J.; Xu, W.; Xia, B.; Skibniewski, M.J. Exploring key indicators of residual value risks in China's public-private partnership projects. J. Manag. Eng. 2018, 34, 04017046. [CrossRef]

21. Ma, G.; Du, Q.; Wang, K. A concession period and price determination model for PPP projects: Based on real options and risk allocation. Sustainability 2018, 10, 706-727.

22. Ye, X.; Yang, J. Research on PPP project pricing based on multi-objective programming model. Stat. Decis. 2012, 6, 74-77.

23. Liu, H.; Sun, H. Selection of social capital for PPP projects based on fuzzy network analysis. Financ. Account. Mon. 2016, 32, 50-54.

24. Shakeri, E.; Dadpour, M.; Jahromi, H.A. The combination of fuzzy electre and swot to select private sectors in partnership projects case study of water treatment project in Iran. Int. J. Civ. Eng. 2015, 13, 55-67.

25. Wang, L. Research on evaluation methods and decision making of PPP project under market economy. Chin. Commer. Theory 2016, 36, 157-158.

26. Liu, X. Market vs. Government in Managing the Chinese Economy. China Research Center, 15 October 2014.

27. Guidance on Encouraging Private Capital to Participate in Public-Private Partnership (PPP) Projects. 2017. Available online: http:/ / www.ndrc.gov.cn/gzdt/201711/t20171130_869138.html (accessed on 27 June 2018).

28. Guidance on Further Encouraging the Vitality of Civilian Effective Investment to Promote the Sustainable and Healthy Development of Economy. 2017. Available online: http://www.gov.cn/zhengce/content/201709/15/content_5225395.htm (accessed on 27 June 2018).

29. Guidance on Innovating the Institutional Mechanism of Rural Infrastructure Investment and Financing. 2017. Available online: http:/ / www.gov.cn/zhengce/content/2017-02/17/content_5168733.htm (accessed on 27 June 2018).

30. Infrastructure and Public Utilities Franchise Management Measures. 2015. Available online: http:/ /fgs.ndrc. gov.cn/zttp/ppplftj/lftj/201605/t20160511_801405.html (accessed on 27 June 2018).

31. Interim Measures for the Administration of Special Subsidy Funds for Preliminary Work of Government and Social Capital Cooperation Projects. 2015. Available online: http:/ / www.ndrc.gov.cn/yjzx/yjzx_add. jsp?SiteId=99 (accessed on 27 June 2018).

32. Notice on Accelerating the Use of Public-Private Partnership (PPP) Mode to Activate Infrastructure Assets. 2017. Available online: http:/ / www.ndrc.gov.cn/gzdt/201707/t20170707_854099.html (accessed on 27 June 2018).

33. Notice on Conscientiously Deepening the Work Related to the Government's Cooperation with Social Capital in the Field of Traditional Infrastructure. 2016. Available online: http://www.ndrc.gov.cn/zcfb/zcfbtz/ 201608/t20160830_816401.html (accessed on 27 June 2018).

34. Notice on Deepening Opinions on Key Work for Deepening Economic System Reform in 2016. 2016. Available online: http://www.gov.cn/zhengce/content/2016-03/31/content_5060062.htm (accessed on 27 June 2018). 
35. Notice on Developing Public-Private Partnership (PPP) Innovation Work in Major Municipal Engineering Sectors. 2016. Available online: http://bgt.ndrc.gov.cn/zcfb/201610/t20161011_822293.html (accessed on 27 June 2018).

36. Notice on the General Office of the State Council of China on Further Opotimization the Work Related to Private Investment. 2016. Available online: http:/ / www.gov.cn/zhengce/content/2016-07/04/content_ 5087839.htm (accessed on 27 June 2018).

37. Notice on Requesting Typical Cases of Traditional Public-Private Partnership (PPP) Projects in the Field of Traditional Infrastructure. 2016. Available online: http:/ /bgt.ndrc.gov.cn/zcfb/201609/t20160906_817790. html (accessed on 27 June 2018).

38. Promotion of Private Investment in Typical Experiences and Practices. 2016. Available online: http:/ / www. ndrc.gov.cn/fzgggz/gdzctz/tzfg/201609/t20160921_819117.html (accessed on 27 June 2018).

39. Promotion Several Policies and Measures for the Healthy Development of Private Investment. 2016. Available online: http:/ / www.ndrc.gov.cn/gzdt/201610/t20161012_822431.html (accessed on 27 June 2018).

40. Ajzen, I. The theory of planned behavior, organizational behavior and human decision processes. J. Leis. Res. 1991, 50, 176-211.

41. Koropp, C.; Kellermanns, F.W.; Grichnik, D.; Stanley, L. Financial decision making in family firms: An adaptation of the theory of planned behavior. Fam. Bus. Rev. 2014, 27, 307-327. [CrossRef]

42. Aibinu, A.A.; Al-Lawati, A.M. Using PLS-SEM technique to model construction organizations' willingness to participate in e-bidding. Autom. Constr. 2010, 19, 714-724. [CrossRef]

43. Cheng, E.W.L. Intentions to form project partnering in Hong Kong: Application of the theory of planned behavior. J. Constr. Eng. Manag. 2016, 142, 04016075. [CrossRef]

44. Xian, Z.; Lu, Y.; Yun, L.; Li, Y.; Fang, J. Formation of inter organizational relational behavior in megaprojects: Perspective of the extended theory of planned behavior. J. Manag. Eng. 2018, 34, 04017052.

45. Tang, T. Research on Bidding Decision-Making of PPP Project Based on the Theory of Planned Behavior and Prospect Theory. Ph.D. Dissertation, Tianjin University, Tianjin, China, 2016.

46. Wu, Z.; Yu, A.T.; Shen, L. Investigating the determinants of contractor's construction and demolition waste management behavior in mainland China. Waste Manag. 2016, 60, 290-300. [CrossRef] [PubMed]

47. Karim Ghani, W.A.; Rusli, I.F.; Biak, D.R.; Idris, A. An application of the theory of planned behaviour to study the influencing factors of participation in source separation of food waste. Waste Manag. 2013, 33, 1276-1281. [CrossRef] [PubMed]

48. Song, H.; Lü, X.; Jiang, Y. The Effects of Characteristics of Tourists on Chinese Outbound Tourism Destination Choice Behavior: An Empirical Study Based on TPB Model. Tour. J. 2016, 43, 33-43.

49. Wibowo, A.; Alfen, H.W. Government-led critical success factors in PPP infrastructure development. Built Environ. Proj. Asset Manag. 2015, 5, 121-134. [CrossRef]

50. Osei-Kyei, R.; Chan, A.P.C. Implementing public private partnership (PPP) policy for public construction projects in Ghana: Critical success factors and policy implications. Int. J. Constr. Manag. 2016, 17, 113-123. [CrossRef]

51. Wang, S.Q.; Tiong, R.L.K.; Ting, S.K.; Ashley, D. Evaluation and management of political risks in China's bot projects. J. Constr. Eng. Manag. 2000, 126, 242-250. [CrossRef]

52. Shan, M.; Chan, A.P.C.; Le, Y.; Hu, Y.; Xia, B. Understanding collusive practices in Chinese construction projects. J. Prof. Issues Eng. Educ. Pract. 2016, 143, 05016012. [CrossRef]

53. Shan, M.; Chan, A.P.; Le, Y.; Hu, Y. Investigating the effectiveness of response strategies for vulnerabilities to corruption in the Chinese public construction sector. Sci. Eng. Ethics 2015, 21, 683-705. [CrossRef] [PubMed]

54. Shan, M.; Le, Y.; Yiu, K.T.; Chan, A.P.; Hu, Y. Investigating the underlying factors of corruption in the public construction sector: Evidence from China. Sci. Eng. Ethics 2017, 23, 1643-1666. [CrossRef] [PubMed]

55. Ozorhon, B.; Oral, K. Drivers of innovation in construction projects. J. Constr. Eng. Manag. 2016, 143, 04016118. [CrossRef]

56. Liu, Q.; Ren, J. A study of the characteristics of social capital participating in public private partnerships-Evidence from Chinese listed firms. Rev. Econ. Manag. 2017, 6, 38-46.

57. Ye, X.; Shi, S.; Liu, L. The choice and driving force of social capital participation in PPP projects in western China. J. Civ. Eng. Manag. 2017, 34, 77-82.

58. Ye, X.; Shi, S.; Chong, H.Y.; Fu, X.; Liu, L.; He, Q. Empirical analysis of firms' willingness to participate in infrastructure PPP projects. J. Constr. Eng. Manag. 2018, 144, 04017092. [CrossRef] 
59. Zhang, G.; Xiao, G. Analysis on the reasons why private enterprises participate in the PPP project "double drop" and policy Suggestions (below). Constr. Enterp. Manag. 2018, 2018, 88-91.

60. Babatunde, S.O.; Perera, S. Barriers to bond financing for public-private partnership infrastructure projects in emerging markets: A case of Nigeria. J. Financ. Manag. Prop. Constr. 2017, 22, 2-19. [CrossRef]

61. Liu, H.; Liu, J. Empirical analysis on the dynamic factors that attract social capital participation in PPP projects. Commer. Econ. Res. 2016, 3, 29-31.

62. Mostaan, K. Stakeholder Alignment Strategies for Highway Infrastructure Public-Private Partnerships. Ph.D. Thesis, Georgia Institute of Technology, Atlanta, GA, USA, 2017.

63. Osei-Kyei, R.; Dansoh, A.; Kuragu, J.K.O.Â. Reasons for adopting public "private partnership (PPP) for construction projects in Ghana. Int. J. Constr. Manag. 2014, 14, 227-238.

64. World Bank. Attracting Investors to African Public-Private Partnerships: A Project Preparation Guide; World Bank Publications: Washington, DC, USA, 2009.

65. Li, B.; Akintoye, A.; Hardcastle, C. Critical success factors for PPP/PFI projects in the UK construction industry. Constr. Manag. Econ. 2005, 23, 459-471. [CrossRef]

66. Ke, Y.; Wang, S.; Chan, A.P.C. Government incentives for private sector involvement in infrastructure PPP projects. J. Tsinghua Univ. 2009, 49, 1480-1483.

67. Li, Y.; liu, M.; Wang, F. Study on project operation mode of large-scale construction enterprises based on PPP mode. Constr. Technol. 2017, 46, 107-112.

68. Liang, L. Research on Investment and Financing of Sewage Treatment Industry Based on PPP Mode-Taking Bishuiyuan as an Example. Ph.D. Thesis, East China University of Science and Technology, Shanghai, China, 2016.

69. Ng, S.T.; Wong, Y.M.W.; Wong, J.M.W. Factors influencing the success of PPP at feasibility stage-A tripartite comparison study in Hong Kong. Habitat Int. 2012, 36, 423-432. [CrossRef]

70. Ng, S.T.; Wong, Y.M.W.; Wong, J.M.W. A structural equation model of feasibility evaluation and project success for public-private partnerships in Hong Kong. IEEE Trans. Eng. Manag. 2010, 57, 310-322. [CrossRef]

71. Akintoye, A.; Hardcastle, C.; Beck, M.; Chinyio, E.; Asenova, D. Achieving best value in private finance initiative project procurement. Constr. Manag. Econ. 2003, 21, 461-470. [CrossRef]

72. Kanji, G.K. Performance measurement system. Total Qual. Manag. 2002, 13, 715-728. [CrossRef]

73. Chan, A.P.C.; Lam, P.T.I.; Chan, D.W.M.; Cheung, E.; Ke, Y. Privileges and attractions for private sector involvement in PPP Projects-A comparison between China and the Hong Kong special administrative region. In Proceedings of the International Structural Engineering and Construction Conference, Vegas, NV, USA, 22-25 September 2009; pp. 751-755.

74. Porter, M.E. How Competitive Forces Shape Strategy. Harv. Bus. Rev. 1979, 57, 137-145.

75. Smith, K.G.; Ferrier, W.J.; Ndofor, H. Competitive Dynamics Research: Critique and Future Directions. In Handbook of Strategic Management; Hitt, M.A., Freeman, R.E., Harrison, J.S., Eds.; Blackwell Publishers: Malden, MA, USA, 2001; pp. 315-361.

76. Mol, M.J.; Birkinshaw, J. The sources of management innovation: When firms introduce new management practices. J. Bus. Res. 2004, 62, 1269-1280. [CrossRef]

77. Chan, A.P.C.; Cheung, E.; Kajewski, S. Factors contributing to successful public private partnership projects. J. Facil. Manag. 2012, 10, 45-58.

78. Dulaimi, M.F.; Alhashemi, M.; Ling, F.Y.Y.; Kumaraswamy, M. The execution of public-private partnership projects in the UAE. Constr. Manag. Econ. 2010, 28, 393-402. [CrossRef]

79. Jefferies, M. Critical success factors of public private sector partnerships: A case study of the Sydney SuperDome. Eng. Constr. Archit. Manag. 2006, 13, 451-462. [CrossRef]

80. Wang, B.; Zhang, X.; Wang, X. Function positioning and construction thinking of PPP industry association. Chin. Gov. Procure. 2018, 2018, 66-69.

81. Long, W.; Li, S.; Xing, D. Environmental performance of industry associations and small and medium-sized enterprises: A perspective of informal environmental regulation effect. Chin. Adm. 2017. [CrossRef]

82. Yuan, J.F.; Skibniewski, M.; Li, Q.; Shan, J. The driving factors of China's public private partnership projects in metropolitian transportation systems: Public sector's viewpoint. Statyba 2010, 16, 5-18. [CrossRef]

83. Almarri, K. Perceptions of the attractive factors for adopting public-private partnerships in the UAE. Int. J. Constr. Manag. 2017. [CrossRef] 
84. Liu, Q.; Zhang, S. Development process, major problems and reform prospects of China's PPP. Financ. Superv. 2017, 4, 5-9.

85. Zou, P.X. An overview of China's construction project tendering. Int. J. Constr. Manag. 2007, 7, $23-39$. [CrossRef]

86. Han, S.H.; Diekmann, J.E. Approaches for making risk-based go/no-go decision for international projects. J. Constr. Eng. Manag. 2001, 127, 300-308. [CrossRef]

87. Ozdoganm, I.D.; Talat Birgonul, M. A decision support framework for project sponsors in the planning stage of build-operate-transfer (BOT) projects. Constr. Manag. Econ. 2000, 18, 343-353. [CrossRef]

88. Liu, T.; Wilkinson, S. Adopting innovative procurement techniques: Obstacles and drivers for adopting public private partnerships in New Zealand. Constr. Innov. 2011, 11, 452-469. [CrossRef]

89. Shen, L.Y.; Li, Q.M.; Drew, D.; Shen, Q.P. Awarding construction contracts on multicriteria basis in China. J. Constr. Eng. Manag. 2004, 130, 385-393. [CrossRef]

90. Walker, C.; Smith, A.J. Privatized Infrastructure: The BOT Approach; Thomas Telford: London, UK, 1995.

91. Ye, K.; Shen, L.; Xia, B.; Li, B. Key attributes underpinning different markup decision between public and private projects: A China study. Int. J. Proj. Manag. 2014, 32, 461-472. [CrossRef]

92. Bryde, D.J.; Robinson, L. Client versus contractor perspectives on project success criteria. Int. J. Proj. Manag. 2005, 23, 622-629. [CrossRef]

93. Peters, D.H.; Phillips, T. Mectizan donation program: Evaluation of a public-private partnership. Trop. Med. Int. Health 2010, 9, A4-A15. [CrossRef] [PubMed]

94. Fu, W.K.; Drew, D.S.; Lo, H.P. Competitiveness of inexperienced and experienced contractors in bidding. J. Constr. Eng. Manag. 2003, 129, 388-395. [CrossRef]

95. Abdul-Aziz, A.R.; Kassim, P.S.J. Objectives, success and failure factors of housing public-private partnerships in Malaysia. Habitat Int. 2011, 35, 150-157. [CrossRef]

96. Gannon, M.J.; Smith, N.J. An effective outline business case to facilitate successful decision-making. Constr. Manag. Econ. 2011, 29, 185-197. [CrossRef]

97. Hwang, B.G.; Zhao, X.; Gay, M.J.S. Public private partnership projects in Singapore: Factors, critical risks and preferred risk allocation from the perspective of contractors. Int. J. Proj. Manag. 2013, 31, 424-433. [CrossRef]

98. Jacobson, C.; Sang, O.C. Success factors: Public works and public-private partnerships. Int. J. Public Sector Manag. 2008, 21, 637-657. [CrossRef]

99. Aziz, A.M.A. Successful delivery of public-private partnerships for infrastructure development. J. Constr. Eng. Manag. 2011, 133, 918-931. [CrossRef]

100. Chan, D.W.M.; Chan, A.P.C.; Lam, P.T.I. A feasibility study of the implementation of public private partnership (PPP) in Hong Kong. In Proceedings of the CIB W89 BEAR 2006 International Conference on Construction Sustainability and Innovation, Hong Kong, China, 10-13 April 2006.

101. Jefferies, M.; Mcgeorge, W.D. Using public-private partnerships (PPPs) to procure social infrastructure in Australia. Engineering 2009, 16, 415-437. [CrossRef]

102. Meng, X.; Zhao, Q.; Shen, Q. Critical success factors for transfer-operate-transfer urban water supply projects in China. J. Manag. Eng. 2011, 27, 243-251. [CrossRef]

103. Albalate, D.; Bel, G.; Geddes, R.R. The determinants of contractual choice for private involvement in infrastructure projects. Public Money Manag. 2015, 35, 87-94. [CrossRef]

104. Hon, C.K.H.; Chan, A.P.C.; Yam, M.C.H. Empirical study to investigate the difficulties of implementing safety practices in the repair and maintenance sector in Hong Kong. J. Constr. Eng. Manag. 2012, 138, 877-884. [CrossRef]

105. Zhao, X.; Hwang, B.G.; Sui, P.L. Understanding enterprise risk management maturity in construction firms. J. Constr. Eng. Manag. 2014, 140, 905-915. [CrossRef]

106. Zheng, J.; Wu, G.; Xie, H. Impacts of leadership on project-based organizational innovation performance: The mediator of knowledge sharing and moderator of social capital. Sustainability 2017, 9, 1893. [CrossRef]

107. Babakus, E.; Mangold, W.G. Adapting the SERVQUALservqual scale to hospital services: An empirical investigation. Health Serv. Res. 1992, 26, 767. [PubMed]

108. Jenkins, G.D.; Taber, T.D. A Monte-Carlo study of factors affecting three indices of composite scale reliability. J. Appl. Psychol. 1977, 62, 392-398. [CrossRef]

109. Saleh, F.; Ryan, C. Analysing service quality in the hospitality industry using the SERVQUAL model. Serv. Ind. J. 1991, 11, 324-345. [CrossRef] 
110. Liu, J.; Zhao, X.; Yan, P. Risk paths in international construction projects: Case study from Chinese contractors. J. Constr. Eng. Manag. 2016, 142, 05016002. [CrossRef]

111. Zahoor, H.; Chan, A.P.C.; Utama, W.P.; Gao, R.; Memon, S.A. Determinants of safety climate for building projects: SEM-based cross-validation study. J. Constr. Eng. Manag. 2017, 143, 05017005. [CrossRef]

112. Eybpoosh, M.; Dikmen, I.; Birgonul, M.T. Identification of risk paths in international construction projects using structural equation modeling. J. Constr. Eng. Manag. 2011, 137, 1164-1175. [CrossRef]

113. Xiong, B.; Skitmore, M.; Xia, B.; Masrom, M.A.; Ye, K.; Bridge, A. Examining the influence of participant performance factors on contractor satisfaction: A structural equation model. Int. J. Proj. Manag. 2014, 32, 482-491. [CrossRef]

114. Reinartz, W.; Haenlein, M.; Henseler, J. An empirical comparison of the efficacy of covariance-based and variance-based SEM. Soc. Sci. Electron. Publ. 2009, 26, 332-344.

115. Dijkstra, T.K. Latent Variables and Indices: Herman Wold's Basic Design and Partial Least Squares; Springer: Berlin/Heidelberg, Germany, 2010; pp. 23-46.

116. Chin, W.W. The partial least square approach to structural equation modeling. In Modern Methods for Business Research; Marcoulides, G.A., Ed.; Erlbaum: Mahwah, NJ, USA, 1998; pp. 295-336.

117. Hair, J.F.; Ringle, C.M.; Sarstedt, M. PIS-SEM: Indeed a silver bullet. J. Mark. Theory Pract. 2011, 19, $139-152$. [CrossRef]

118. Ning, Y.; Ling, F.Y.Y. Reducing hindrances to adoption of relational behaviors in public construction projects. J. Constr. Eng. Manag. 2013, 139, 04013017. [CrossRef]

119. Zhao, X.; Hwang, B.G.; Sui, P.L. Critical success factors for enterprise risk management in Chinese construction companies. Constr. Manag. Econ. 2013, 31, 1199-1214. [CrossRef]

120. Rajendran, S.; Gambatese, J.; Behm, M. Impact of green building design and construction on worker safety and health. J. Constr. Eng. Manag. 2009, 135, 1058-1066. [CrossRef]

121. Tixier, A.; Hallowell, M.; Albert, A.; van Boven, L.; Kleiner, B. Psychological antecedents of risk-taking behavior in construction. J. Constr. Eng. Manag. 2014, 140, 04014052. [CrossRef]

122. Hwang, B.G.; Shan, M.; Looi, K.Y. Key constraints and mitigation strategies for prefabricated prefinished volumetric construction. J. Clean. Prod. 2018, 183, 183-193. [CrossRef]

123. Hair, J.F.; Black, W.C.; Babin, B.J.; Anderson, R.E. Multivariate Data Analysis, 7th ed.; Prentice Hall: Upper Saddle River, NJ, USA, 2010.

124. Fornell, C.; Larcker, D.F. Evaluating structural equation models with unobservable variables and measurement error. J. Mark. Res. 1981, 18, 39-50. [CrossRef]

125. Doloi, H. Rationalizing the implementation of web-based project management systems in construction projects using PLS-SEM. J. Constr. Eng. Manag. 2014, 140, 615-621. [CrossRef]

126. Tonglet, M.; Philips, P.S.; Read, A.D. Using the theory of planned behavior to investigate the determinants of recycling behavior: A case study from Brixworth, UK. Resour. Conserv. Recycl. 2004, 41, 191-214. [CrossRef]

127. Nunnally, J.C. Psychometric Theory; McGraw-Hill: New York, NY, USA, 1978.

128. Campbell, D.T.; Fiske, D.W. Convergent and discriminant validation by the multitrait-multimethod matrix. Psychol. Bull. 1959, 56, 81-105. [CrossRef] [PubMed]

129. Ling, F.Y.Y.; Ning, Y.; Ke, Y.; Kumaraswamy, M.M. Modeling relational transaction and relationship quality among team members in public projects in Hong Kong. Autom. Constr. 2013, 36, 16-24. [CrossRef]

130. Ning, Y. Quantitative effects of drivers and barriers on networking strategies in public construction projects. Int. J. Proj. Manag. 2014, 32, 286-297. [CrossRef]

131. Cenfetelli, R.T.; Bassellier, G. Interpretation of formative measurement in information systems research. Mis Q. 2009, 33, 689-707. [CrossRef]

132. Hulland, J. Use of partial least squares (PLS) in strategic management research: A review of four recent studies. Strateg. Manag. J. 2015, 20, 195-204. [CrossRef]

133. Hair, J.F.; Hult, G.T.M.; Ringle, C.M.; Sarstedt, M. A Primer on Partial Least Squares Structural Equation Modeling (PLS-SEM); SAGE Publications, Inc.: Los Angeles, CA, USA, 2014.

134. Li, J.; Zou, P.X. Fuzzy AHP-based risk assessment methodology for PPP projects. J. Constr. Eng. Manag. 2011, 137, 1205-1209. [CrossRef]

135. Zhang, W.-K.; Yang, Y.-H.; Wang, Y.-Q. An empirical study on key factors influencing the performance of public-private partnerships (PPP) in some transitional countries. J. Public Manag. 2010, 7, 103-112. 
136. Wang, S. The Government Credibility as the PPP Mode “Obstacle”. 2015. Available online: http:/ / www. ccgp.gov.cn/specialtopic/pppzt/news/201509/t20150914_5844025.htm (accessed on 12 June 2018).

137. Qi, X.; Ke, Y.; Wang, S. Based on the case analysis of the main risk factors for PPP projects in China. China Soft Sci. 2009, 5, 107-113.

(c)

(C) 2018 by the authors. Licensee MDPI, Basel, Switzerland. This article is an open access article distributed under the terms and conditions of the Creative Commons Attribution (CC BY) license (http:/ / creativecommons.org/licenses/by/4.0/). 